\title{
HISTORICAL AND STATISTICAL DATA ON THE DEVELOPMENT OF THE DOMESTIC ALCOHOLIC BEVERAGES INDUSTRY
}

\author{
Sergey A. Khurshudyan, Konstantin V. Kobelev, Anastasiya E. Ryabova* \\ All-Russian Scientific Research Institute of the Brewing, Non-Alcoholic and Wine Industry - \\ Branch of the V. M. Gorbatov Federal Research Center for Food Systems of RAS, Moscow, Russia
}

KEY WORDS:

alcoholic beverages, statistical data, beverage history, wine, beer, cognac

\section{ABSTRACT}

The method of historical and statistical data analysis makes it possible to identify development and characteristic patterns, both temporary and permanent, production criteria for various branches of the food industry. The application of this method made it possible to trace formation of the alcohol industry in Russia and identify critical historical events that influenced its development. The article presents and analyzes statistical data on the production of the main types of alcoholic beverages industry since 1913.

\section{Introduction}

Every person, every nation at all times had, has and will have its own favorite beverages, which correspond to the national flavor and personal preferences. Therefore, the range of beverages produced in the world is very large. It is also difficult to analyze in detail the history of origin and statistics of the beverages production and consumption. This is due to the fact that not only each kind and type of beverage, but also each brand has its own rich history, covered with legends about the origin and production, which has always aroused the interest of not only specialists, but also a wide range of consumers. When analyzing the available statistical data, a problem arises related to the allocation of individual subgroups of produced beverages, especially in modern times.

To begin with, consider a brief history of the alcoholic beverages' main types origin.

\section{Main part}

In literary sources, the history of wine is most fully covered, which is associated with its special role in the history of mankind $[1,2,3,4,5,6]$. Wine along with flour, oil, etc. refer to the first food products obtained by humans as a result of primary raw materials processing [7]. The word wine comes from the Latin word «vinum». It is possible that the Latin word «vinum» was transformed into other European languages, and then into Slavic. Another opinion should not be ruled out that it is based on the Indo-European «voino», which passed into the Semitic (Hebrew) «jajin», the Arabic dialectal «waynun», and later - the ancient Greek «ojnos». The analysis of the transitions and their sequence allows tracing the ways of spreading the winemaking culture in Europe $[1,2,8]$.

Experts do not have a consensus about when and where winemaking appeared. One can only reliably assert that grapes were cultivated already 5-7 thousand years ago [8].

In 1668, a Benedictine monk of Dom Pierre Perignon (16381715), a winegrower and winemaker from the Abbey of Hautevilliers in the center of Champagne, receives a wine with sparkling properties and original taste, which quickly gains worldwide fame after the information publication in 1718 about the champagne production technology [7,9].

The first mention of the cognac production in literature is found in 1630. Then winemakers used distillation to produce grape vodka from wine. And for a higher concentration of al- cohol, secondary distillation was performed. The new beverage was named after the place of its production - the Cognac city (department of Charente). The production of modern cognac began only at the beginning of the 18th century, when, due to the war between France and England, French winemakers discovered that when stored for a long time in oak barrels, alcohols acquire a special pleasant bouquet and taste.

Cognacs produced outside the Charente wine region are called brandy. The name of the drink comes from the word «brandwijn» or «brandewyn», which in Dutch means «distilled» or «burnt wine».

The history of whiskey production goes back more than five centuries (the production of whiskey in Scotland in 1494-1495 was founded by the monk John Cor), but a number of experts dispute this statement and believe that whiskey began to be produced in Ireland as early as the X-XI centuries. [10]. Whiskey is a product of the distillation of fermented wort made from rye, corn and barley malt, followed by aging in oak barrels fired from the inside [11].

Beer - belongs to the oldest low-alcohol beverages, the history of which is more than 5 thousand years old. The first mention of beer among the Slavs dates back to 448 . According to the geography of prevalence and the variety of trade marks, beer can be considered the most demanded beverage, the production technology of which has been improving for centuries [12].

The homeland of vodka is Russia - this is the opinion of V.V. Pokhlebkin, having studied a large number of historical materials (archives, archaeological data, etc.) $[13,14]$. At the same time, there is evidence, which should be treated with a great deal of doubt, that vodka began to be produced in Poland in 1405 [10].

A number of national beverages should also be attributed to vodkas - kahasa (Brazilian made from sugarcane), pulque and tequila (Mexican made from fermented agave juice), bamboo (Indonesian bamboo), hanshina and maotai (Chinese wheat and rice), shochu and sake (Japanese rice), plum brandy (Bulgarian plum vodka), mulberry oghi (Armenian mulberry), chacha (Georgian grape), arak (from fruit and vegetable raw materials, from rice, from a date palm), grappa (Italian from grape pomace), etc. [10].

The beginning of the appearance of domestic winemaking and wine can be considered the XVII-XVIII centuries [7,15].

It is assumed that at the beginning of the XVII century Persian merchants brought Transcaucasian vines to Astrakhan and handed them over to a local monk for planting near the monas- 
tery. Viticulture and winemaking in this area began to develop successfully. In 1613, wine began to be supplied for the royal table. According to the surviving documents, in 1658 the governor Romodanovsky sent 41 barrels of church wine to Moscow. From the tsar's charter dated January 17, 1659 addressed to the Astrakhan governors Prince Dmitry Lvov and Nikifor Beklemeshev, it is known that Paskayunos Padavin was in charge of state winemaking, who was ordered to prepare exclusively church wine $[2,8,15,16]$.

In the lower reaches of the Don, winemaking began in the time of Peter I, who in 1706 ordered the planting of vineyards there. In 1794, the Don Cossacks were resettled to the Kuban, and vineyards were also planted there. The region from which vineyards spread to Russia was also Crimea $[17,18]$.

Wine production in Russia almost until the end of the 19th century was of an artisanal nature [19,20].

At the beginning of the twentieth century, there were few large vineyards in Russia. Winemaking was also technically imperfect. The grapes were processed using primitive techniques and technology.

In 1913, about 3 million dcl of grape wine were produced. Expensive vintage wines were imported from abroad, mainly from France, Germany, Greece, Austria [19].

Sparkling wines prepared according to French technology were first obtained in 1799 in the Crimea, but in the middle of the 19 th century this production was practically closed. And it was restored thanks to the efforts of L. S. Golitsyn (1845-1915) at the very end of the XIX - beginning of the XX century. Champagne was used only for domestic Russian consumption, so this production did not receive much development. The highest level of champagne production in Russia was reached in 1913-479 thousand bottles $[21,22,23,24]$.

Brandy production originated in Kizlyar, where the production of grape alcohol already existed. At the end of the XIX century production of cognac began in Russia (Tbilisi, 1888). Cognac production received successful development: by the end of 1913, there were already 43 factories in Russia, which in total produced 435.4 thousand dcl (354 thousand buckets; 1 bucket was considered equal to 12.3 liters) of cognac [10,13,25].

Brewing on the territory of Russia has the longest history, which was formed in ancient times. By 1913, 1,016 breweries were operating in Russia, but beer production was insignificant. In terms of beer production, Russia lagged behind the United States 7 times, Germany -6.2 times, and England -5.3 times.

By 1914, brewing industries in Russia had formed into an industry with a fairly high level of production concentration: 85 of the largest breweries with an annual capacity of over 24,600 hl each produced $58.5 \%$ of the total beer output, and 822 plants with an annual capacity of up to $12,300 \mathrm{hl}$ produced only $26,2 \%$ of all products of the brewing industry [20,26,27].

In connection with the outbreak of the First World War, the sale of all alcoholic beverages, including beer, was prohibited; all breweries were closed.

In distillery production by 1913 the number of small factories was decreasing, and the share of large and medium-sized distilleries accounted for $86 \%$ of the total produced alcohol. Distilleries of an industrial type, in contrast to agricultural distilleries, producing alcohol only from September 1 to May 1, were the largest of the enterprises producing alcohol, better technically equipped, had more advanced technology and production organization.

Before the First World War, Russia took the first place in the production of alcohol in the world (65 million dcl against a world production of 250 million dcl). In Russia, 3.3 liters per capita were produced, of which $89.6 \%$ was consumed for drinking, and $10.4 \%$ - for technical needs (for comparison: Germany produced
5.4 liters per capita, of which $51.8 \%$, and for technical $-48.2 \%$ ) [19.28].

Table 1 shows data on the alcoholic beverages production in 1913 [19].

Information on the alcoholic beverages production in $\mathbf{1 9 1 3}$

\begin{tabular}{lc}
\hline \multicolumn{1}{c}{ Products } & Production \\
\hline Ethyl alcohol, mln dcl & 46.7 \\
\hline Vodka and vodka products, mln dcl & 118.9 \\
\hline Beer, mln dcl & 80.6 \\
\hline
\end{tabular}

It is necessary to note one specific feature characteristic of Russian enterprises at the beginning of the 20th century. Among the enterprises, a special group stood out - qualification enterprises. Qualification enterprises included enterprises that used steam engines or 15 or more workers in the absence of steam engines [7]. Table 2 shows data on qualification enterprises in Russia at the beginning of the 20th century.

The structure of qualification food production

Table 2

\begin{tabular}{|c|c|c|c|c|}
\hline \multirow{2}{*}{ Food production } & \multicolumn{2}{|c|}{ Enterprises } & \multicolumn{2}{|c|}{ Workers } \\
\hline & число & $\%^{1}$ & число & $\%$ \\
\hline $\begin{array}{l}\text { Production of kvass, vinegar, mineral } \\
\text { waters and sparkling beverages }\end{array}$ & 58 & 0.73 & 1000 & 0.26 \\
\hline Malt & 101 & 1.27 & 3452 & 0.90 \\
\hline $\begin{array}{l}\text { Distillery, yeast-distillery and } \\
\text { alcohol-purifying }\end{array}$ & 2754 & 34.65 & 43775 & 11.42 \\
\hline Vodka and liqueur & 64 & 0.80 & 2665 & 0.69 \\
\hline Wine and cognac & 68 & 0.86 & 964 & 0.26 \\
\hline Brewing and mead & 1139 & 14.33 & 23246 & 6.07 \\
\hline Wine warehouses ${ }^{2}$ & 342 & 4.30 & 39473 & 7.95 \\
\hline
\end{tabular}

${ }^{1}$ Data on the percentage refer to the total number of food production in the country, including those not included in the list given in column 1 (for example, coffee, tobacco, salt, tea, etc.); therefore, their sum is less than $100 \%$.

${ }^{2}$ In state-owned wine warehouses, alcohol was monopolistically processed into vodka, so the aforementioned vodka and liqueur production has such a small share in total.

The First World War dealt a severe blow to the food industry in Russia. For 1914-1917 according to official data, 1,087 qualification food establishments were closed [29]. The volume of distillery production decreased over the specified period by more than 10 times (it should be noted that the sale of vodka during the war in the country was prohibited).

The 1917 revolution and the ensuing Civil War caused a further decline in the food industry. Measures to food production nationalization could not have an impact on the growth of output, but, to a certain extent, reduced the rate of decline in output. Table 3 shows data on the decline in the production of alcoholic beverages in 1920 compared to the pre-war level.

Reduction of alcoholic beverages in 1920 compared to the pre-war level

\begin{tabular}{lc}
\hline \multicolumn{1}{c}{ Production } & $\mathbf{1 9 2 0}$ in\% to 1913 \\
\hline Distillery, yeast and vodka & 0.5 \\
Beer-mead & 0.3
\end{tabular}

1920 was a year of extreme decline in domestic food production, when, after a four-year world and three-year Civil War, all foundations of the industry were shaken to the ground and in terms of production level, the state of the material and technical and raw material base, it was thrown back many years [20,30]. 
Only by the end of the 20s of the twentieth century there was a stable growth in food production, but in many areas the results of 1913 were unattainable. So, in 1928, 23.3 million dcl of crude alcohol were produced, which amounted to $50 \%$ of its production in 1913 [26.28].

In the first five-year plans (1928-1932 and 1933-1937) 6 new distilleries were put into operation. The planned economy, the dispersal of food enterprises throughout the USSR, the creation of powerful industries in fast-growing cities allowed in 1940 to significantly exceed the indicators of 1913 (Table 4).

The Second World War interrupted the development of the food industry and required a radical restructuring of all its work in relation to wartime conditions. During the war, 649 distilleries were destroyed $[28,32]$.

By the beginning of 1946, 3,223 food enterprises were restored, including distilleries and wineries [32]. Nevertheless, the loss of production capacity and the raw material base was so great that the level of production of the alcoholic beverage industry was thrown back many years as a result of the war.

The main task of the fourth five-year plan (1946-1950) was to restore the affected areas of the country, restore the pre-war level of industry, and then surpass it. Since 1950, the implementation of the fifth five-year plan (1950-1955) began, in which significant emphasis was placed on improving the performance of the food industry in 1940.

A significant increase in the scale of production of alcoholic beverages in the fifth five-year period is evidenced by the indicators of the production of its most important types, shown in Table 5 [28,31].
It should be noted that in 1958 the growth in the production of agricultural raw materials not only provided domestic food production with the necessary raw materials, but also a certain surplus arose, which made it possible to proceed to a further increase in the number of industries producing alcoholic beverages.

The development of the food industry in subsequent years began to experience difficulties, there were signs of stagnation and crisis phenomena (mid-70s), but they did not affect alcoholic beverages (see Table 5).

The next five-year plan (1971-1975) partially retained the inertia of the positive development of the food industry, but by the end of the five-year period, stagnation was clearly evident. The accumulation of manifestations of stagnant phenomena continued in the next two five-year plans (1981-1985 and 19861990) $[13,19]$.

The collapse of the USSR in 1991 led to the creation of modern Russia, but caused colossal damage to the country's economy, including the production of the main types of alcoholic beverages (Table 6) [32].

At the turn of the 21st century, the Russian alcohol industry faced the challenge of survival and preservation. At this time, a modern classification of the main branches of the food industry was introduced [33,34,35,36,37].

Table 7 provides a list of the main sectors and industries (sub-sectors) of the modern alcoholic industry. It should be noted that the production of beer is combined with the production of nonalcoholic beverages [33,36].

Production of the main types of alcoholic beverages during the pre-war five-year plans

\begin{tabular}{|c|c|c|c|c|c|c|}
\hline \multirow{2}{*}{ Products } & \multicolumn{3}{|c|}{ Years } & \multirow{2}{*}{$\begin{array}{c}1937 \text { in\% to } \\
1913 \text { r. }\end{array}$} & \multicolumn{2}{|c|}{1940 in\% to } \\
\hline & 1913 & 1937 & 1940 & & 1913 & 1937 \\
\hline Crude alcohol, mln dcl & 46.7 & 76.7 & 89.9 & 164.2 & 192.5 & 117.2 \\
\hline Vodka and vodka products, mln dcl & 118.9 & 89.7 & 92.5 & 75.4 & 77.7 & 103.1 \\
\hline Grape wine, thousands of dcl & 30000 & 9015 & 19695 & - & 65.6 & 218.4 \\
\hline Cognacs, thousands of dcl & 125 & 278 & 268 & - & 214.4 & 97.4 \\
\hline Champagne, thousands of bottles & 479 & 556 & 8019 & - & 17 times & 14.4 times \\
\hline Beer, thousands of bottles & 80.6 & 89.7 & 121.3 & 111.2 & 150.4 & 135.3 \\
\hline
\end{tabular}

Production of the main types of alcoholic beverages in the 50s - 60s of XX

\begin{tabular}{|c|c|c|c|c|c|c|c|c|c|c|}
\hline \multirow{2}{*}{ Products } & \multicolumn{3}{|c|}{ Years } & \multicolumn{2}{|c|}{$1955 \mathrm{in \%}$ to } & \multicolumn{3}{|c|}{ Years } & \multirow{2}{*}{$\begin{array}{c}1965 \mathrm{in} \% \\
\text { to } 1958\end{array}$} & \multirow{2}{*}{$\begin{array}{c}1970 \mathrm{in} \% \\
\text { to } 1965\end{array}$} \\
\hline & 1940 & 1950 & 1955 & 1940 & 1950 & 1958 & 1965 & 1970 & & \\
\hline Crude alcohol, mln dcl & 89.9 & 73.0 & 127.8 & 142.1 & 175.0 & 163.9 & 236.0 & - & 143.9 & - \\
\hline Grape wine, mln dcl & 19.7 & 23.8 & 47.4 & 239.1 & 197.9 & 61.8 & 133.9 & 268.0 & 216.7 & 200.1 \\
\hline Beer, mln dcl & 121.3 & 130.8 & 181.4 & 152.2 & 141.2 & 199.1 & 316.9 & 419.0 & 159.2 & 132.2 \\
\hline
\end{tabular}

Production of alcoholic beverages in 1992-2000

Table 6

\begin{tabular}{|c|c|c|c|c|}
\hline \multirow{2}{*}{ Products } & \multicolumn{3}{|c|}{ Years } & \multirow{2}{*}{2000 in\% to 1992} \\
\hline & 1992 & 1995 & 2000 & \\
\hline \multicolumn{5}{|c|}{ Alcoholic beverages: } \\
\hline in absolute alcohol, mln dcl & 76,3 & 60,8 & 74,4 & 97,5 \\
\hline \multicolumn{5}{|l|}{ in kind, mln dcl: } \\
\hline vodka and alcoholic products & 152,0 & 123,0 & 123,0 & 80,9 \\
\hline grape wines & 39,8 & 15,2 & 24,1 & 60,5 \\
\hline fruit wines & 2,5 & 7,6 & 2,8 & 112,0 \\
\hline champagne and sparkling wines & 7,6 & 8,2 & 6,8 & 89,5 \\
\hline cognacs & 1,8 & 0,9 & 1,7 & 94,5 \\
\hline beer & 279,0 & 213,0 & 516,0 & 184,9 \\
\hline
\end{tabular}


List of the main branches of the alcohol industry

\begin{tabular}{|c|c|c|}
\hline No. & Branch & Production \\
\hline \multirow[t]{2}{*}{1} & \multirow{2}{*}{$\begin{array}{l}\text { Alcoholic } \\
\text { and distillery }\end{array}$} & 1. Alcoholic \\
\hline & & 2. Distillery \\
\hline \multirow[t]{5}{*}{2} & \multirow[t]{5}{*}{ Winemaking } & $\begin{array}{l}\text { 1. Production of wine materials and wines from grapes } \\
\text { and fruit and berry raw materials (primary winemaking) }\end{array}$ \\
\hline & & $\begin{array}{l}\text { 2. Processing and packaging of wines, finishing of fin- } \\
\text { ished products (secondary winemaking) }\end{array}$ \\
\hline & & 3. Production of champagne and sparkling wines \\
\hline & & 4. Production of cognac distillate and cognacs \\
\hline & & 5. Processing of secondary raw materials for winemaking \\
\hline \multirow[t]{7}{*}{3} & \multirow{7}{*}{$\begin{array}{l}\text { Non-alcoholic } \\
\text { beer }\end{array}$} & 1. Malt \\
\hline & & 2. Brewing \\
\hline & & 3. Non-alcoholic \\
\hline & & 4. Kvass \\
\hline & & 5. Extraction and packaging of mineral waters \\
\hline & & 6. Production of beverage concentrates \\
\hline & & 7. Carbon dioxide production \\
\hline
\end{tabular}

The collapse of political power in 1991, the subsequent sharp change in the social way of life of the people, the disruption of financial and industrial ties - all this could not affect the economic indicators of the country, both in the short and long term. In the period 1991-2000 there was a collapse of industrial production, including the release of food products. The collapse affected both the number of operating enterprises, and, naturally, the volume of production [33,34,35,36,37].

The indicators of the use of sown areas can serve as evidence of overcoming the crisis of 1991-2000. The growth in acreage indicates the confidence of agricultural producers in the future, which is a kind of guarantee for food producers, including alcohol producers (Table 8) [38,39].

The results of the alcohol industry in Russia for 2000-2011 show that the industry overcame the impact of the 2008 crisis and, based on the results of 2011, as a whole reached a stable level of development. The decline in vodka consumption is a positive trend against the background of the population's desire for a healthy lifestyle. The reserve made for the future allowed the continued stable development of the food industry.

Production of alcoholic beverages in 2010-2011

Table 8

\begin{tabular}{lccc}
\hline \multirow{2}{*}{\multicolumn{1}{c}{ Products }} & \multicolumn{2}{c}{ Years } & $\begin{array}{c}\text { Rate,\% } \\
\text { period of } \\
\end{array}$ \\
\cline { 2 - 4 } & $\mathbf{2 0 1 0}$ & $\mathbf{2 0 1 1}$ & $\begin{array}{c}\text { 2011 to the } \\
\text { period of } \\
\text { 2010 }\end{array}$ \\
\hline Beer, mln dcl & 977.4 & 994.1 & 101.7 \\
\hline Vodka and alcoholic products, mln dcl & 106.3 & 93.9 & 88.4 \\
\hline $\begin{array}{l}\text { Low alcohol beverages (with an alcohol } \\
\text { content not exceeding 9\%), mln dcl }\end{array}$ & 30.2 & 31.9 & 105.5
\end{tabular}

The statement that the food industry in Russia has taken the path of formation and consistent development is confirmed by real production data. Considering, that the period under review (2012-2017) includes the time of significant sanctions restrictions and the crisis of 2013, the preservation and growth of indicators of the production activity of the beverage industry suggests that the alcohol industry is in a stable state $[28,31,32,33,34$, $35,36,37,38,39,40,41,42,43,44,45]$, although there is a decrease in output for certain types of products (Table 9).

Table 10 shows the final results of the alcohol industry for 2018-2019 [46,47].

It should be noted that in a number of cases, a decrease in volumes is due to the fact that new product subgroups are allocated. For example, due to changes in legislation, the classification group "beer" is divided into two - "beer" and "beer beverages", which introduces time complexity in statistical reports.

\section{Conclusion}

Thus, the historical and statistical collection of information makes it possible to clearly trace the development of the alcohol industry in Russia and the influence of various historical factors on it. The above data confirm that the beverage industry maintains a positive development trend.

Table 9

Beverage production. Release of the main products in 2012-2017

\begin{tabular}{|c|c|c|c|c|c|c|c|}
\hline Products & 2012 & 2013 & 2014 & 2015 & 2016 & 2017 & $\begin{array}{l}\text { Rate,\% period } \\
\text { of } 2017 \text { to } 2012\end{array}$ \\
\hline Beer, excluding brewing waste, mln dcl & 948.9 & 831.0 & 766.5 & 730.3 & 763.2 & 744.5 & 78.5 \\
\hline Ethyl alcohol from food raw materials (excluding distillates), mln dcl & 48.4 & 46.2 & 40.1 & 42.4 & 47.0 & 66.3 & 137.0 \\
\hline Vodka, mln dcl & 97.8 & 85.7 & 66.6 & 63.9 & 73.2 & 79.8 & 81.6 \\
\hline Cognac, mln dcl & 9.8 & 7.4 & 6.9 & 7.7 & 7.6 & 8.5 & 86.7 \\
\hline Wine, mln dcl & 36.7 & 33.9 & 32.1 & 40.0 & 36.9 & 32.0 & 87.2 \\
\hline Sparkling and champagne wines, mln dcl & 0.7 & 17.2 & 15.6 & 16.1 & 14.7 & 12.8 & 1828.6 \\
\hline Low alcohol beverages (with an alcohol content not exceeding $9 \%$ ), mln dcl & 20.5 & 26.3 & 17.1 & 9.5 & 6.7 & 6.4 & 31.2 \\
\hline
\end{tabular}

Results of the food industry in 2018-2019

Table 10

\begin{tabular}{|c|c|c|c|}
\hline \multirow{2}{*}{ Products } & \multicolumn{2}{|c|}{ Years } & \multirow{2}{*}{$\begin{array}{l}\text { Rate,\% period of } 2019 \text { to } \\
\text { the period of the } 2018\end{array}$} \\
\hline & 2018 & 2019 & \\
\hline Beer, excluding brewing waste, mln dcl & 774.7 & 770.7 & 99.5 \\
\hline Ethyl alcohol from food raw materials (excluding distillates) - total, mln dcl & 59.2 & 55.4 & 93.5 \\
\hline Vodka, mln dcl & 79.8 & 83.6 & 104.7 \\
\hline Cognac, mln dcl & 8.4 & 9.2 & 109.5 \\
\hline Sparkling and champagne wines, mln dcl & 12.4 & 13.2 & 106.4 \\
\hline Wine, mln dcl & 30.4 & 32.8 & 107.9 \\
\hline Low alcohol beverages (with an alcohol content not exceeding 9\%), mln dcl & 6.8 & 7.6 & 111.7 \\
\hline
\end{tabular}




\section{REFERENCES}

1. Zaychik, Ts.R. (2001). Wine, books, history. Moscow: - $151 \mathrm{p}$.

2. Dzhonson, Kh. (2004). History of Wine. Moscow: BBPG. - 480 p. ISBN: 5-93679-059-2 (c)

3. Zaychik, Ts. (2006). Dionysius and the Bacchanalia. Pages, 11(2), 281-295.

4. Zaychik, Ts.R., Zaychik B. Ts. (2006). Crushers for grapes. Wort drippers. Moscow. -87 p.

5. Zaychik, Ts.R., Zaychik B. Ts. (2005). Presses for grapes. Moscow. - 91 p.

6. The history of wine in civilization and literature. (1999). Moscow: Belovodye. - 544 p. ISBN: 5-88901-018-2

7. Khurshudyan, S.A., Zaychik, Ts.R. (2009). History of food production and development of the food industry in Russia: a tutorial. Moscow: DeL print - 203 p. ISBN: 978-5-94343-189-0

8. Afanas'yev, V.I., Kulikov, I.M., Tyatyushkina, T.A. (2013). Grapes and wine through the ages. Moscow: All-Russian Institute of Selection and Technology of Horticulture and Nursery of the Russian Agricultural Academy. $-306 \mathrm{p}$

9. Zybtsev, Yu.E. (2003) Champagne and other sparkling wines of France. Moscow: Zhigulsky Publishing House. - 301 p. ISBN: 5-93679-033-9

10. Brum, D. (2004). Strong alcoholic drinks of the world. Moscow: Eksmo. 224 p. ISBN: 5-699-05125-2

11. Tuzmukhamedov, E.R. (2003). Whiskey of the world. Moscow: Zhigulsky Publishing House. -335 p. ISBN: 5-93679-035-5

12. Monte, P. (2002). Egypt of the Ramses. Smolensk: Rusich. - 414 p. ISBN5-8138-0083-2

13. Pokhlebkin, V.V (2004). History of the most important foods. Moscow: ZAO Tsentrpoligraf. - 553 p. ISBN: 5-9524-1255-6, 978-5-9524-34585, 978-5-9524-4717-2

14. Sergeyev, V.N. (2003). 500 years of Russian vodka. Production of alcohol and alcoholic beverages, 1, 8-9.

15. Oganesyants, L.A., Panasyuk, A.L., Fedorenko, B.N. (2020). General technology of wine: textbook. St. Petersburg: Professiya. - 352 p. ISBN: $978-$ 5-6043942-3-6

16. Afanas'yev, V.I., Borisova, A.A., Zarmayev, A.A., Kulikov, I.M., Tyatyushkina, T.A. (2014). Grapes and Wine Through the Ages. V. 2. Moscow: AllRussian Institute of Selection and Technology of Horticulture and Nursery of the Russian Agricultural Academy. -284 p.

17. Chebotareva, A.I. (2013). Excursion into the history of Don viticulture and winemaking. Proceedings of the conference: Achievements, problems and prospects for the development of the domestic wine-making industry at the present stage. Novocherkassk: All-Russian research Institute of viticulture and winemaking named Y. I. Potapenko. - p. 285-291.

18. Tsygankova, Ye., Shishkina, N.A. (2017). Winemaking in the Kuban - history and modernity. Resorts. Service. Tourism, 1-2(34-35), 117-122.

19. Complete encyclopedia of Russian agriculture and related sciences. St. Petersburg: Publishing house A. F. Devriena. - Vol. 18 (1900-1912).

20. Arens, F., Arndt, K., Dalen, G. etc. (1904). Industry and technology. Encyclopedia of Industrial Knowledge. V. 1. Agriculture and processing of its most important products. - St. Petersburg: Prosveshcheniye. -745 p.

21. Bakir', V.V. (2017). History and development of viticulture and winemaking in the Crimea. Collection of works of the III scientific-practical conference of the teaching staff, graduate students, students and young scientists "Days of Science KFU named after V. I. Vernadsky". Simferopol: KFU named after V. I. Vernadsky, 198-199.

22. Dzarasov, A.A., Zelinskaya, Ye.L. (2018). History of Massandra as the main center of viticulture and winemaking of the Crimea in the 19th cen- tury. Bulletin of the North Ossetian State University named after K. L. Khet agurov, 2, 23-26.

23. Andreyeva, A.S., Zhane, S.R. (2020). On the history of the development of winemaking in the Republic of Crimea. Social and Humanitarian Bulletin, 26, 95-99. ISBN: 978-5-91221-448-6

24. Zelinskaya, Ye.L., Shushpanova, Yu.D. (2018). Wine extravaganza of Prince Golitsyn. Collection of works of the scientific conference "Problems and prospects of tourism development in the southern federal district". Simferopol: KFU named after V. I. Vernadsky, 93-97.

25. Garunova, N.N. (2019). The history of cognac production in the Kizlyar region of Dagestan (1930-1949). Locus: people, society, cultures, meanings, $1,37-51$.

26. Alekseyeva, N. (2006). All about beer. Moscow: AST. -160 p.

27. Petrochenkov, A.V. (2003). Beer. Moscow: Zhigulevsky Publishing House. - 303 p. ISBN: 5-93679-038-X

28. Filatov, K. Ye. (1965). The main stages in the development of the food industry in the USSR. Moscow: VZIPP. $-200 \mathrm{p}$.

29. Statistics of industries subject to excise duty for 1914. - Petrograd: 1916. $-78 \mathrm{p}$

30. Krzhizhanovskiy, G.M. (1927). Ten years of economic construction in the USSR (1917-1927). Moscow: Planned economy. - $132 \mathrm{p}$.

31. Sivolap, I.K. (1952). The food industry of the USSR but a new rise. Moscow: Gospolitizdat. -92 p.

32. Russia in numbers. 2010: Brief statistical collection. Rosstat. (2010). Moscow. -558 p.

33. Tul'chinskiy, L.I. (1974). Classification of the food industry of the USSR Moscow: Food industry. -39 p.

34. Panfilova, V. A. (2010). System development of food technology technology: textbook. Moscow: KolosS. - 762 p. ISBN: 978-5-9532-0813-0

35. Filatov, K. Ye. (2008). The main stages of development of the food industry in the USSR. Moscow: TSINTI Goskomzag.

36. Filatov, O. K. (2006). Development of the food industry in Russia. Study guide. Moscow: MGTA. -200 p.

37. Filatov, K. Ye., Filatov, O. K. (2009). History of the Russian food industry. Educational and practical guide. Moscow: MGZIPP.

38. Russia in numbers. 2012: Brief statistical collection. Rosstat. (2012). Moscow. $-576 \mathrm{p}$.

39. The results of the work of enterprises of the food and processing industry in Russia for January-December 2011. (2012). Food industry, 3, 6-7.

40. The results of the work of enterprises of the food and processing industry in Russia for January-December 2012. (2013). Food industry, 3. 6-7.

41. The results of the work of enterprises of the food and processing industry in Russia for January-December 2013. (2014). Food industry, 3, 6-7.

42. The results of the work of enterprises of the food and processing industry in Russia for January-December 2014. (2015). Food industry, 3, 6-7.

43. The results of the work of enterprises of the food and processing industry in Russia for January-December 2015. (2016). Food industry, 3, 6-7.

44. The results of the work of enterprises of the food and processing industry in Russia for January-December 2016. (2017). Food industry, 3, 6-7.

45. The results of the work of enterprises of the food and processing industry in Russia for January-December 2017. (2018). Food industry, 3, 6-7.

46. The results of the work of enterprises of the food and processing industry in Russia for January-December 2018. (2019). Food industry, 3, 6-7.

47. The results of the work of enterprises of the food and processing industry in Russia for January-December 2019. (2020). Food industry, 3, 6-7.

\section{AUTHOR INFORMATION}

Sergey A. Khurshudyan - Doctor of technical science, Professor, senior scientist of Interdisciplinary scientific and technical center of food quality monitoring, All-Russian Scientific Research Institute of Brewing, Beverage and Wine Industry - Branch of V. M. Gorbatov Federal Research Center for Food Systems of RAS, 119021, Moscow, Rossolimo str., 7.

Tel. +7-499-245-61018. E-mail: xca020149@rambler.ru

ORCID: https://orcid.org/0000-0001-7735-7356

Konstantin V. Kobelev - Doctor of technical science, acting director, All-Russian Scientific Research Institute of Brewing, Beverage and Wine Industry Branch of V. M. Gorbatov Federal Research Center for Food Systems of RAS, 119021, Moscow, Rossolimo str., 7.

Tel.+7-499-255-27-39.E-mail: k.kobelev55@mail.ru

ORCID: https://orcid.org/0000-0002-3619-6282

Anastasiya E. Ryabova - Candidate of technical sciences, scientist of Interdisciplinary scientific and technical center of food quality monitoring, All-Russian Scientific Research Institute of Brewing, Beverage and Wine Industry - Branch of V. M. Gorbatov Federal Research Center for Food Systems of RAS, 119021, Moscow, Rossolimo str., 7.

Tel.: +7-499-245-61-18. E-mail: aeryabova@yandex.ru

* corresponding author

ORCID: https://orcid.org/ 0000-0002-5712-2020

All authors bear responsibility for the work and presented data.

All authors made an equal contribution to the work.

The authors were equally involved in writing the manuscript and bear the equal responsibility for plagiarism.

The authors declare no conflict of interest.

Received 30.10.2020 Accepted in revised 30.11.2020 Accepted for publication 24.12.2020 